\title{
Analytical Analysis of the Interfacial Stress in Damaged Reinforced Concrete Beams Strengthened by Bonded Composite Plates
}

\author{
T. Hassaine Daouadji \\ University of Tiaret (Université Ibn Khaldoun de Tiaret), Tiaret, Algerie \\ daouadjitah@yahoo.fr
}

УДК 539.4

\section{Аналитический расчет межповерхностных напряжений в повреж- денных железобетонных балках, армированных композитными пластинами}

\section{Т. Хассайн Дауаджи}

Университет им. Ибн Халдуна, Тиарет, Алжир

Предложен аналитический метод оценки межповерхностных напряжений в слоях поврежденных железобетонных балок, укрепленных наружными композитными пластинами из армированного волокнами углепластика. Предложена модель, которая, в отличие от существующих решений, учитывает наличие межповерхностных касательных деформаций путем постулирования линейного распределения касательных напряжений по глубине железобетонной балки. Разработана анизотропная модель разрушения, описывающая процесс повреждения железобетонной балки. Установлено, что повреждение существенно влияет на величину межповерхностных напряжений в поврежденных железобетонных балках, армированных композитными пластинами.

Ключевые слова: поврежденная бетонная балка, межповерхностные напряжения, упрочнение, композитные пластины.

Introduction. Advanced composite materials, e.g., fiber-reinforced polymers (FRP), have found their new applications in the rehabilitation of reinforced concrete structure $[1,2]$. Compared with the traditional materials, composite materials have some unique features, i.e., high strength and stiffness to weight ratio, attractive corrosion resistance and ease of handling and application [3, 4]. Among these materials, carbon fiber-reinforced polymers (CFRP) are extensively used because of their unparalleled characteristics [5, 6]. The transferring of stresses from concrete to the FRP reinforcement is central to the reinforcement effect of FRP-strengthened concrete structures. This is because the stresses are susceptible to cause the undesirable premature and brittle failure, such as debonding of the soffit plate from the RC beam. This debonding failure mode is brittle and prevents the full utilization of the tensile strength of the bonded plate. It is therefore important to understand the mechanism of this debonding failure mode and develop sound design rules. This brittle mode of failure is a result of the high shear and vertical normal (peeling) stress concentrations arising at the edges of the bonded FRP strip. Hence, this limited area in the close vicinity of the bonded strip 
edge, subjected to high peeling and interfacial shear stresses, proves to be among the most critical parts of the strengthened beam. Consequently, the determination of interfacial stresses has been researched for the last decade for beams bonded with either steel or advanced composite materials [7, 8]. In particular, several closed-form analytical solutions have been developed [9, 10]. All these solutions are for linear elastic materials and employ the same key assumption that the adhesive is subject to normal and shear stresses that are constant across the thickness of the adhesive layer. It is this key assumption that enables relatively simple closed-form solutions to be obtained. In the existing solutions, two different approaches have been employed. Roberts [11] and Roberts and Haji-Kazemi [12] used a staged analysis approach, while Vilnay [9], Taljsten [13], Malek et al. [14], and Smith and Teng [10] considered directly deformation compatibility conditions.

Rabinovich and Frostig [15] have presented a higher-order approximate interfacial stress. A disadvantage, of this solution is that, unlike the other solutions, explicit expressions are not available for the interfacial stresses, so results are not easily obtainable, which makes it difficult to be exploited in developing a design rule. Shen et al. [16] presented a higher-order in which explicit expressions have been obtained, but these are much more complex than the expressions from other analyses.

Most of the research efforts have focused on strengthening of undamaged RC beams with externally bonded sheets, whereas the interfacial stresses in damaged RC beams strengthened by externally bonded FRP strips have not been fully studied yet.

The main objective of the present study is to analyze the interfacial stresses in damaged RC beams strengthened with FRP plate. The simple approximate closedform solutions discussed in this paper provide a useful but simple tool for understanding the interfacial behavior of an externally bonded FRP plate on the damaged concrete beam with the consideration of the effect of the fiber orientations.

\section{Theoretical Analysis and Solutions Procedure.}

1.1. Material Properties of Damaged Plates. Voyiadjis and Kattan [17] proposed an anisotropic damaged model, in which the elastic energy configuration of deformed and damaged state is equivalent to the elastic energy configuration of deformed but undamaged state. Based on this assumption, the relations of elastic constants of damaged state and undamaged state can be expressed as

$$
\widetilde{E}_{11}=E_{11}\left(1-\phi_{11}\right)^{2}, \quad \widetilde{E}_{22}=E_{22}\left(1-\phi_{22}\right)^{2},
$$

where $\widetilde{E}_{11}, \widetilde{E}_{22}$ and $E_{11}, E_{22}$ are the elastic constants of damaged and undamaged state, respectively, and $\phi_{11}$ and $\phi_{22}$ are damaged variables. Hence, the material properties of the damaged plate can be represented by replacing the above elastic constants with the effective ones defined in Eq. (1). A convenient way to determine $\phi_{11}$ and $\phi_{22}$ is to utilize the damage law postulated by Yu et al. [18] for concrete. It is given as

$$
\phi_{22}=\frac{1}{2 N_{C}+1}\left[\frac{\varepsilon_{2}}{\varepsilon_{f}^{c}}\right]^{N_{C}}, \quad \phi_{11}=H \phi_{22} \quad(H>1)
$$


and

$$
N_{C}=\frac{\sqrt{E_{f}^{C}}}{2\left(\sqrt{E_{C}}-\sqrt{E_{f}^{C}}\right)},
$$

where $E_{f}^{C}$ is the tangential elastic modulus when the stress reaches its peak, $E_{C}$ is the initial elastic modulus, $\varepsilon_{f}^{c}$ is the failure strain, and $\varepsilon_{2}$ is the current state of strain. Value of $H$ is a constant determined by experiments, for example, when $E_{C}=49.49 \mathrm{GPa}, N_{C}=3.65, H=3$, and $v=0.2$, then $\phi_{22}=0.12048\left(\varepsilon_{2} / \varepsilon_{f}^{c}\right)^{3.65}$.

1.2. Mathematical Formulation of the Present Method. A differential section $d x$, can be cut out from the FRP reinforced concrete beam (Fig. 1), as shown in Fig. 2. The composite beam is made from three materials: concrete (or reinforced concrete), adhesive layer and FRP reinforcement. In the present analysis, linear elastic behavior is regarded to be for all the materials; the adhesive is assumed to play a role only in transferring the stresses from the concrete to the FRP reinforcement, and the stresses in the adhesive layer do not vary through the direction of the thickness.

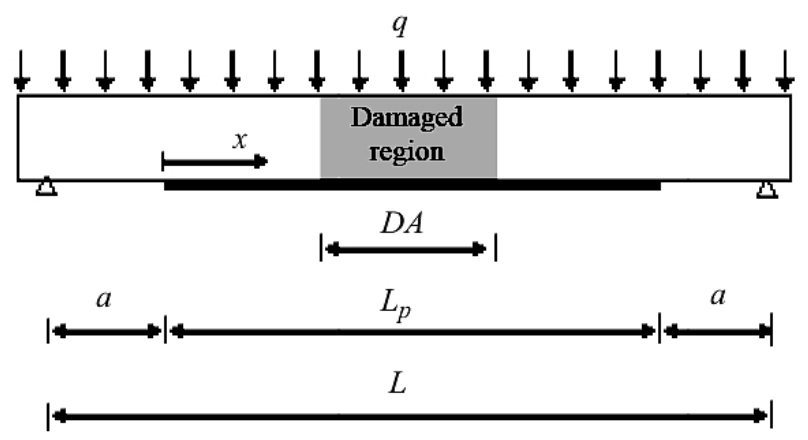

Fig. 1. Simply supported beam strengthened with bonded FRP plate.

1.2.1. Basic Equation of Elasticity. The strain $\varepsilon_{1}(x)$ in the concrete beam near adhesive interface can be expressed as

$$
\varepsilon_{1}(x)=\frac{d u_{1}(x)}{d x}=\frac{e M_{1}(x)}{E_{1} I_{1}}-\frac{N_{1}(x)}{E_{1} A_{1}} .
$$

The laminate theory is used to estimate the strain $\varepsilon_{2}(x)$ in the external FRP reinforcement near adhesive interface. Furthermore, it is assumed that the ply arrangement of the plate is symmetrical

$$
\varepsilon_{2}(x)=\frac{d u_{2}}{d x}=-D_{11}^{\prime} \frac{t_{2}}{2 b_{2}} M_{2}(x)+A_{11}^{\prime} \frac{N_{2}(x)}{b_{2}},
$$

where $u_{1}(x)$ and $u_{2}(x)$ are horizontal displacements of the concrete and the external FRP reinforcement near interface, respectively, $M_{1}(x)$ and $M_{2}(x)$ are 
bending moments applied in the concrete and the external FRP reinforcement, respectively, $E_{1}$ is the Young modulus of the concrete, $I_{1}$ is the second moment area, $e$ is distance from the neutral axis to the bottom of RC beam, $N_{1}$ and $N_{2}$ are axial forces applied in the concrete and the external FRP reinforcement, respectively, $b_{2}$ is the width of the plate, $t_{2}$ is thickness of the external reinforcement, $\left[A^{\prime}\right]=\left[A^{-1}\right]$ is the inverse of the extensional matrix $[A]$, and $\left[D^{\prime}\right]=\left[D^{-1}\right]$ is the inverse of the flexural matrix.
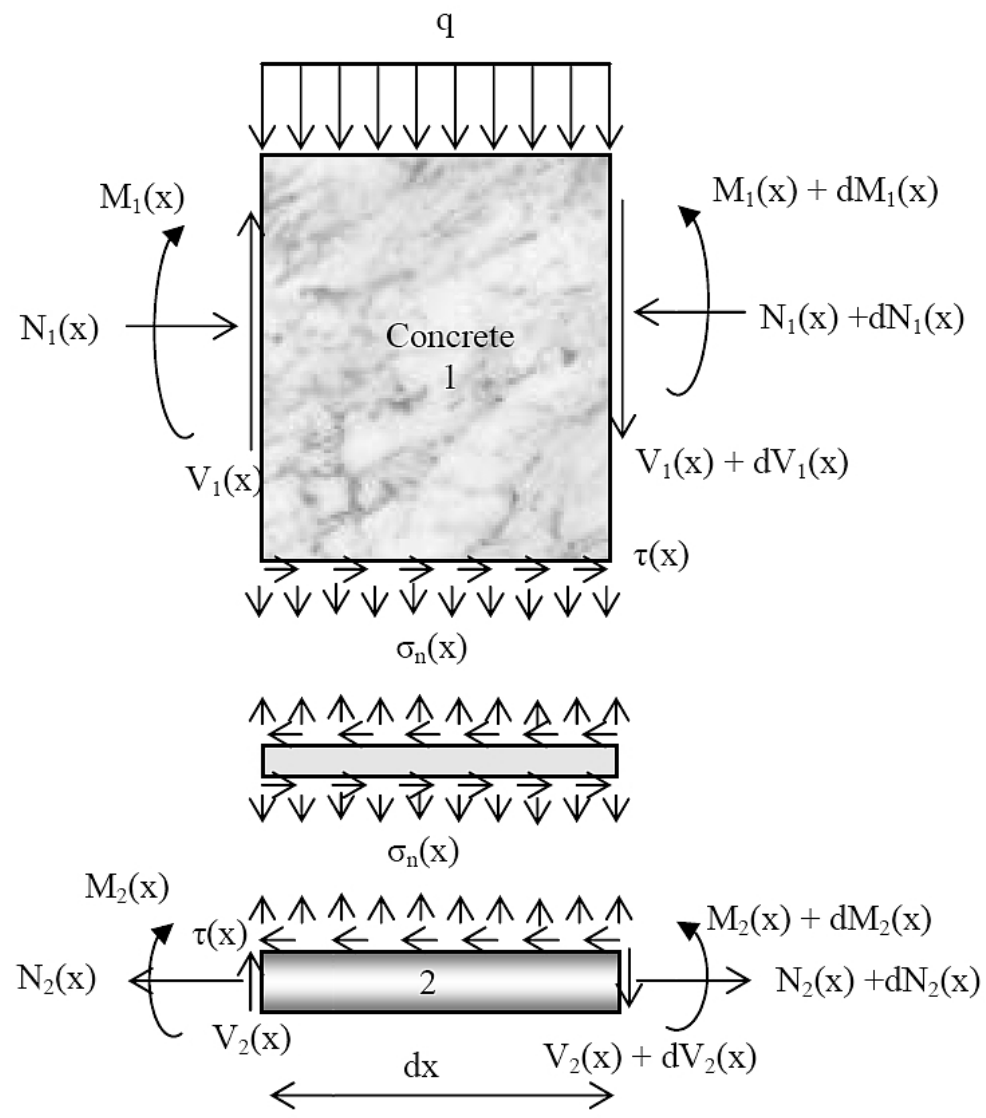

Fig. 2. Forces in infinitesimal element of a soffit-plated beam.

By adopting the equilibrium conditions of the concrete, we have:

Along $x$-direction:

$$
\frac{d N_{1}(x)}{d x}=\tau(x) b_{2},
$$

where $\tau(x)$ is shear stress in the adhesive layer.

Along $y$-direction:

$$
\frac{d V_{1}(x)}{d x}=-\left[\sigma_{n}(x) b_{2}+q\right],
$$

where $V_{1}(x)$ is shear force applied in the concrete, $\sigma_{n}(x)$ is normal stress in the adhesive layer, $q$ is the uniformly distributed load, and $b_{1}$ is width of RC beam. 
Moment equilibrium:

$$
\frac{d M_{1}(x)}{d x}=V_{1}(x)-\tau(x) b_{2} e .
$$

The equilibrium of the external FRP reinforcement along the $x$-and $y$-direction and moment equilibrium can also be written as:

Along $x$-direction:

$$
\frac{d N_{2}(x)}{d x}=\tau(x) b_{2}
$$

Along $y$-direction:

$$
\frac{d V_{2}(x)}{d x}=\sigma_{n}(x) b_{2}
$$

Moment equilibrium:

$$
\frac{d M_{2}(x)}{d x}=V_{2}(x)-\tau(x) b_{2} \frac{t_{2}}{2},
$$

where $V_{2}(x)$ is shear force applied in the external FRP reinforcement.

1.2.2. Shear Stress Distribution along the FRP Concrete Interface. The shear stress in the adhesive can be expressed as follows:

$$
\tau(x)=K_{s} \Delta u(x)=K_{s}\left[u_{2}(x)-u_{1}(x)\right]
$$

where $K_{s}$ is shear stiffness of the adhesive per unit length and can be derived as

$$
K_{s}=\frac{\tau(x)}{\Delta u(x)}=\frac{\tau(x)}{\Delta u(x) / t_{a}} \frac{1}{t_{a}}=\frac{G_{a}}{t_{a}},
$$

$\Delta u(x)$ is relative horizontal displacement at the adhesive interface, $G_{a}$ is the shear modulus in the adhesive, and $t_{a}$ is the thickness of the adhesive.

Differentiating Eqs. (4), (5), and (12) with respect to $x$, respectively:

$$
\frac{d \tau(x)}{d x}=K_{s}\left[A_{11}^{\prime} \frac{N_{2}(x)}{b_{2}}-D_{11}^{\prime} \frac{t_{2}}{2 b_{2}} M_{2}(x)+\frac{N_{1}(x)}{E_{1} A_{1}}-\frac{e M_{1}(x)}{E_{1} I_{1}}\right] .
$$

Assuming equal curvature in the beam and the FRP plate, the relationship between the moments in the two adherends can be expressed as

$$
M_{1}(x)=R M_{2}(x)
$$

with

$$
R=\frac{E_{1} I_{1} D_{11}^{\prime}}{b_{2}}
$$


Moment equilibrium of the differential segment of the plated beam in Fig. 2 gives:

$$
M_{T}(x)=M_{1}(x)+M_{2}(x)+N(x)\left(e+t_{a}+\frac{t_{2}}{2}\right),
$$

$M_{T}(x)$ is the applied moment, and $N(x)$ is given as follows:

$$
N(x)=N_{1}(x)=N_{2}(x)=b_{2} \int_{0}^{x} \tau(x) d x .
$$

The bending moment in $\mathrm{RC}$ beam, expressed as a function of the total applied moment and the interfacial shear stress, is given as

$$
M_{1}(x)=\frac{R}{R+1}\left[M_{T}(x)-b_{2} \int_{0}^{x} \tau(x)\left(e+t_{a}+\frac{t_{2}}{2}\right) d x\right]
$$

and

$$
M_{2}(x)=\frac{1}{R+1}\left[M_{T}(x)-b_{2} \int_{0}^{x} \tau(x)\left(e+t_{a}+\frac{t_{2}}{2}\right) d x\right]
$$

The first derivative of the bending moment in each adherend gives:

$$
\frac{d M_{1}(x)}{d x}=\frac{R}{R+1}\left[V_{T}(x)-b_{2} \tau(x)\left(e+t_{a}+\frac{t_{2}}{2}\right)\right]
$$

and

$$
\frac{d M_{2}(x)}{d x}=\frac{1}{R+1}\left[V_{T}(x)-b_{2} \tau(x)\left(e+t_{a}+\frac{t_{2}}{2}\right)\right] .
$$

Differentiating Eq. (14):

$$
\frac{d^{2} \tau(x)}{d x^{2}}=K_{S}\left(\frac{-t_{2}}{2 b_{2}} D_{11}^{\prime} \frac{d M_{2}(x)}{d x}+\frac{A_{11}^{\prime}}{b_{2}} \frac{d N_{2}(x)}{d x}-\frac{e}{E_{1} I_{1}} \frac{d M_{1}(x)}{d x}+\frac{1}{E_{1} A_{1}} \frac{d N_{1}(x)}{d x}\right) \text {. }
$$

Substitution of the shear forces [Eqs. (21) and (22)] and axial forces [Eq. (18)] into Eq. (23) gives the following governing differential equation for the interfacial shear stress:

$$
\frac{d^{2} \tau(x)}{d x^{2}}-K_{s}\left(A_{11}^{\prime}+\frac{b_{2}}{E_{1} A_{1}}+\frac{\left(e+\frac{t_{2}}{2}\right)\left(e+t_{a}+\frac{t_{2}}{2}\right)}{E_{1} I_{1} D_{11}^{\prime}+b_{2}} b_{2} D_{11}^{\prime}\right) \tau(x)+
$$




$$
+K_{S}\left(\frac{e+\frac{t_{2}}{2}}{E_{1} I_{1} D_{11}^{\prime}+b_{2}} D_{11}^{\prime}\right) V_{T}(x)=0 .
$$

For simplicity, the general solutions presented below are limited to loading which is either concentrated or uniformly distributed over part or the total span of the beam, or both. For such loading, $d^{2} V_{T}(x) / d x^{2}=0$, and the general solution to Eq. (24) is given by

$$
\tau(x)=B_{1} \cosh (\lambda x)+B_{2} \sinh (\lambda x)+m_{1} q\left(\frac{L}{2}-x-a\right),
$$

where

$$
\lambda^{2}=K_{s}\left(A_{11}^{\prime}+\frac{b_{2}}{E_{1} A_{1}}+\frac{\left(e+\frac{t_{2}}{2}\right)\left(e+t_{a}+\frac{t_{2}}{2}\right)}{E_{1} I_{1} D_{11}^{\prime}+b_{2}} b_{2} D_{11}^{\prime}\right)
$$

and

$$
m_{1}=\frac{K_{s}}{\lambda^{2}}\left(\frac{e+\frac{t_{2}}{2}}{E_{1} I_{1} D_{11}^{\prime}+b_{2}} D_{11}^{\prime}\right)
$$

$B_{1}$ and $B_{2}$ are constant coefficients determined from the boundary conditions. In the present study, a simply supported beam is investigated which is subjected to a uniformly distributed load as shown in Fig. 1. The constants of integration need to be determined by applying suitable boundary conditions.

The first boundary condition is applied bending moment at $x=0$. Here, the moment at the plate end $M_{2}(0)$ and the axial force of either the concrete beam or FRP plate $\left[N_{1}(0)=N_{2}(0)\right]$ are zero. As a result, the moment in the section at the plate curtailment is resisted by the beam alone and can be expressed as

$$
M_{1}(0)=M_{T}(0)=\frac{q a}{2}(L-a)
$$

Applying the above boundary condition in Eq. (14):

$$
\frac{d \tau(x=0)}{d x}=-m_{2} M_{T}(0) \quad \text { and } \quad m_{2}=\frac{e K_{s}}{E_{1} I_{1}} .
$$

By substituting Eq. (25) into (29), $B_{2}$ can be determined as

$$
B_{2}=-\frac{q a m_{2}}{2 \lambda}(L-a)+\frac{m_{1}}{\lambda} q
$$


The second boundary condition requires zero interfacial shear stress at midspan due to symmetry of the applied load. Value of $B_{1}$ can therefore be determined as

$$
B_{1}=\frac{a q m_{2}}{2 \lambda}(L-a) \tanh \left(\frac{\lambda L_{p}}{2}\right)-\frac{q m_{1}}{\lambda} \tanh \left(\frac{\lambda L_{p}}{2}\right) .
$$

For practical cases $\lambda L_{p} / 2>10$ and as a result $\tanh \left(\lambda L_{p} / 2\right) \approx 1$. So the expression for $B_{1}$ can be reduced to

$$
B_{1}=\frac{a q m_{2}}{2 \lambda}(L-a)-\frac{q m_{1}}{\lambda}=-B_{2} .
$$

Substitution of $B_{1}$ and $B_{2}$ into Eq. (25) gives an expression for the interfacial shear stress at any point

$$
\tau(x)=\left[\frac{m_{2} a}{2}(L-a)-m_{1}\right] \frac{q e^{-\lambda x}}{\lambda}+m_{1} q\left(\frac{L}{2}-a-x\right) \quad 0 \leq x \leq L_{p},
$$

where $q$ is the uniformly distributed load and $x, a, L$, and $L_{p}$ are defined in Fig. 1.

1.2.3. Normal Stress Distribution along the FRP Concrete Interface. The normal stress in the adhesive can be expressed as follows:

$$
\sigma_{n}(x)=K_{n} \Delta w(x)=K_{n}\left[w_{2}(x)-w_{1}(x)\right],
$$

where $K_{n}$ is normal stiffness of the adhesive per unit length and can be deduced as

$$
K_{n}=\frac{\sigma_{n}(x)}{\Delta w(x)}=\frac{\sigma_{n}(x)}{\Delta w(x) / t_{a}}\left(\frac{1}{t_{a}}\right)=\frac{E_{a}}{t_{a}}
$$

$w_{1}(x)$ and $w_{2}(x)$ are the vertical displacements of adherend 1 and 2 respectively. Differentiating Eq. (34) twice results in

$$
\frac{d^{2} \sigma_{n}(x)}{d x^{2}}=K_{n}\left[\frac{d^{2} w_{2}(x)}{d x^{2}}-\frac{d^{2} w_{1}(x)}{d x^{2}}\right] .
$$

Considering the moment-curvature relationships for the beam to be strengthened and the external reinforcement, respectively:

$$
\frac{d^{2} w_{1}(x)}{d x^{2}}=-\frac{M_{1}(x)}{E_{1} I_{1}}, \quad \frac{d^{2} w_{2}(x)}{d x^{2}}=-\frac{D_{11}^{\prime} M_{2}(x)}{b_{2}} .
$$

Based on the equilibrium equations (6)-(11), the governing differential equations for the deflection of adherends 1 and 2, expressed in terms of the interfacial shear and normal stresses, are given as follows: 
Adherend 1:

$$
\frac{d^{4} w_{1}(x)}{d x^{4}}=\frac{1}{E_{1} I_{1}} b_{2} \sigma_{n}(x)+\frac{e}{E_{1} I_{1}} b_{2} \frac{d \tau(x)}{d x}+\frac{q}{E_{1} I_{1}} .
$$

Adherend 2:

$$
\frac{d^{4} w_{2}(x)}{d x^{4}}=-D_{11}^{\prime} \sigma_{n}(x)+D_{11}^{\prime} \frac{t_{2}}{2} \frac{d \tau(x)}{d x}
$$

Substitution of Eqs. (38) and (39) into the fourth derivation of the interfacial normal stress obtainable from Eq. (34) yields the following governing differential equation for the interfacial normal stress:

$$
\begin{gathered}
\frac{d^{4} \sigma_{n}(x)}{d x^{4}}+K_{n}\left(D_{11}^{\prime}+\frac{b_{2}}{E_{1} I_{1}}\right) \sigma_{n}(x)- \\
-K_{n}\left(D_{11}^{\prime} \frac{t_{2}}{2}-\frac{e b_{2}}{E_{1} I_{1}}\right) \frac{d \tau(x)}{d x}+\frac{q K_{n}}{E_{1} I_{1}}=0 .
\end{gathered}
$$

The general solution to this fourth-order differential equation is

$$
\begin{gathered}
\sigma_{n}(x)=e^{-\beta x}\left[C_{1} \cos (\beta x)+C_{2} \sin (\beta x)\right]+ \\
+e^{\beta x}\left[C_{3} \cos (\beta x)+C_{4} \sin (\beta x)\right]-n_{1} \frac{d \tau(x)}{d x}-n_{2} q .
\end{gathered}
$$

For large values of $x$ it is assumed that the normal stress approaches zero, and as a result $C_{3}=C_{4}=0$. The general solution therefore becomes:

$$
\sigma_{n}(x)=e^{-\beta x}\left[C_{1} \cos (\beta x)+C_{2} \sin (\beta x)\right]-n_{1} \frac{d \tau(x)}{d x}-n_{2} q
$$

where

$$
\begin{aligned}
\beta & =\sqrt[4]{\frac{K_{n}}{4}\left(\frac{b_{2}}{E_{1} I_{1}}+D_{11}^{\prime}\right)}, \\
n_{1} & =\left(\frac{e b_{2}-D_{11}^{\prime} E_{1} I_{1} \frac{t_{2}}{2}}{D_{11}^{\prime} E_{1} I_{1}+b_{2}}\right),
\end{aligned}
$$

and

$$
n_{2}=\frac{1}{D_{11}^{\prime} E_{1} I_{1}+b_{2}} .
$$


The constants $C_{1}$ and $C_{2}$ in Eq. (42) are written as follows:

$$
\begin{gathered}
C_{1}=\frac{K_{n}}{2 \beta^{3} E_{1} I_{1}}\left[V_{T}(0)+\beta M_{T}(0)\right]-\frac{n_{3}}{2 \beta^{3}} \tau(0)+\frac{n_{1}}{2 \beta^{3}}\left(\frac{d^{4} \tau(0)}{d x^{4}}+\beta \frac{d^{3} \tau(0)}{d x^{3}}\right), \\
C_{2}=-\frac{K_{n}}{2 \beta^{2} E_{1} I_{1}} M_{T}(0)-\frac{n_{1}}{2 \beta^{2}} \frac{d^{3} \tau(0)}{d x^{3}}
\end{gathered}
$$

where

$$
n_{3}=b_{2} K_{n}\left(\frac{e}{E_{1} I_{1}}-\frac{D_{11}^{\prime} t_{2}}{2 b_{2}}\right) .
$$

The above expressions for the constants $C_{1}$ and $C_{2}$ have been left in terms of the bending moment $M_{T}(0)$ and shear force $V_{T}(0)$ at the end of the soffit plate.

2. Comparison of Analytical Solutions. A comparison of the interfacial shear and normal stresses from the different existing closed-form solutions and the present new solution is undertaken in this section. An undamaged RC beam bonded with a CFRP soffit plate is considered. The beam is simply supported and subjected to a uniformly distributed load. A summary of the geometric and material properties is given in Table 1. The span of the RC beam is $3000 \mathrm{~mm}$, the distance from the support to the end of the plate is $300 \mathrm{~mm}$ and the uniformly distributed load is $50 \mathrm{kN} / \mathrm{m}$.

$\mathrm{T}$ a b 1 e 1

Geometric and Material Properties

\begin{tabular}{|c|c|c|c|c|c|c||}
\hline \hline Material & $E_{11}, \mathrm{GPa}$ & $E_{22}, \mathrm{GPa}$ & $G_{12}, \mathrm{GPa}$ & $v_{12}$ & Width $(\mathrm{mm})$ & Depth $(\mathrm{mm})$ \\
\hline CFRP plate & 140 & 10 & 5 & 0.28 & $b_{2}=200$ & $t_{2}=4$ \\
\hline GFRP plate & 50 & 10 & 5 & 0.28 & $b_{2}=200$ & $t_{2}=4$ \\
\hline RC beam & 30 & 30 & - & 0.18 & $b_{1}=200$ & $t_{1}=300$ \\
\hline Adhesive layer & 3 & 3 & - & 0.35 & $b_{2}=200$ & $t_{a}=4$ \\
\hline
\end{tabular}

Figure 3 plots the interfacial shear and normal stresses near the plate end for the example RC beam bonded with a CFRP plate for the uniformly distributed load case. Overall, the predictions of the different solutions agree closely with each other. The interfacial normal stress is seen to change sign at a short distance away from the plate end.

3. Parametric Studies. In this section, numerical results of the present solutions are presented to study the effect of various parameters on the distributions of the interfacial stresses in a damaged RC beam bonded with an FRP plate. A damaged state is described through the incorporation of damage variable $\phi_{11}$ in the same way as is described by Shen et al. [19]. These results are intended to demonstrate the main characteristics of interfacial stress distributions in these strengthened beams. 


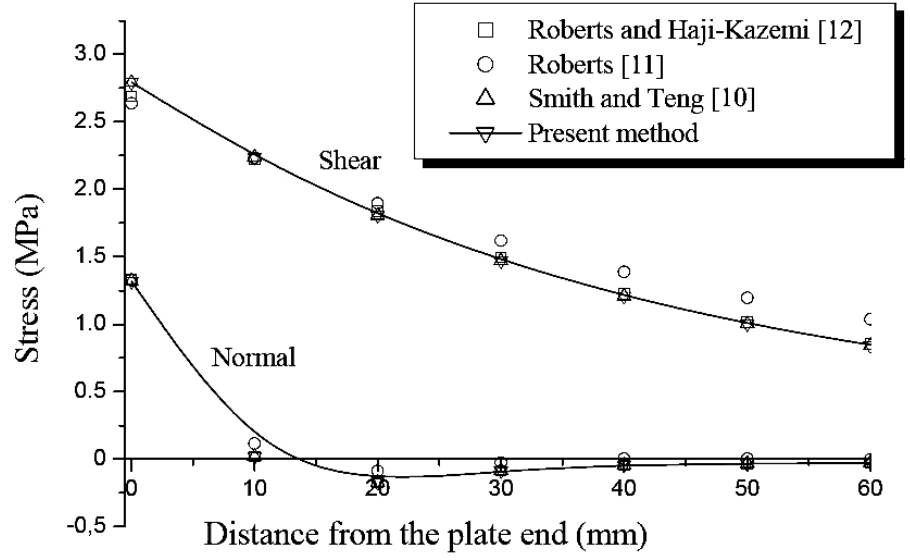

Fig. 3. Comparison of interfacial shear and normal stresses for an RC beam with a bonded CFRP soffit plate $\left[0_{16}\right]_{S}$ subjected to a uniformly distributed load.

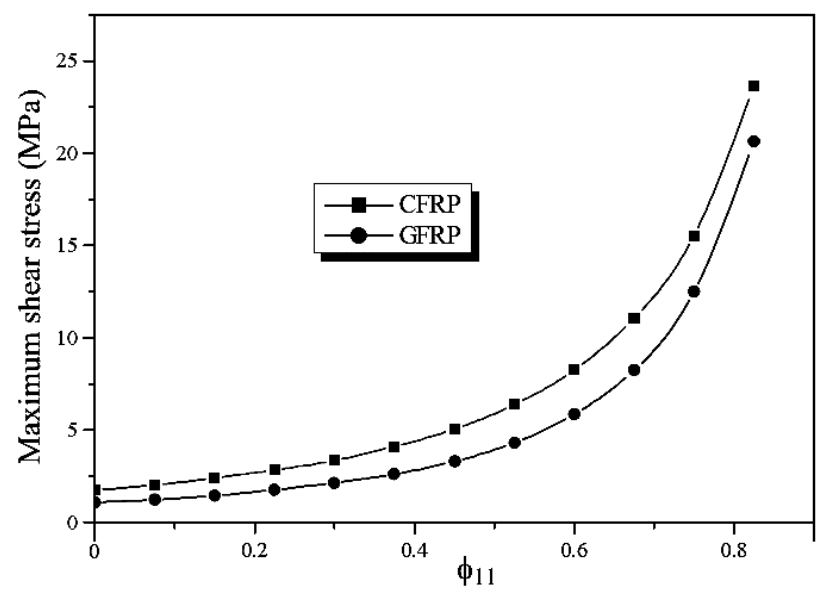

Fig. 4. Effects of damage on the maximum interfacial shear stress of RC beam strengthened by a CFRP or GFRP plate $\left[0_{16}\right]_{S}$.

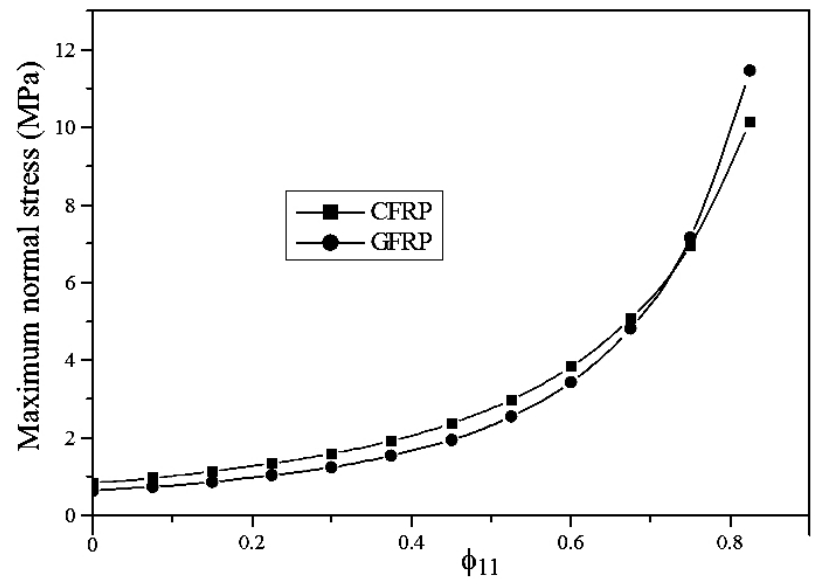

Fig. 5. Effects of damage on the maximum interfacial normal stress of RC beam strengthened by a CFRP or GFRP plate $\left[0_{16}\right]_{S}$. 
3.1. Effect of Damage on the Maximum Interfacial Stresses. Figures 4 and 5 show the effect of damage extent on maximum shear and normal interfacial stresses, respectively, for the two types of FRP materials. The results show that when the damage variable $\phi_{11}$ increases from 0 to 0.375 , the maximum interfacial stresses increase slowly. However, it can be seen that from 0.375 to 0.825 , these stresses increase rapidly.

3.2. Effect of FRP Strip Thickness. Peak shear and peeling stresses for various thicknesses of the FRP strip appear in Fig. 6. The damage variables are taken as $\phi_{22}=0.12048$ and $\phi_{11}=3 \phi_{22}$, which are corresponding to the peak stress, that is $\varepsilon_{2}=\varepsilon_{f}^{c}$ in Eq. (2). The results reveal that thickness of the FRP strip significantly increases the edge peeling and shear stresses. Generally, the thickness of FRP plate used in practical engineering is very small, as compared with one of steel plate. Therefore, the fact of the smaller interfacial stress level and concentration should be one of advantages of retrofitting by FRP over by steel plate.

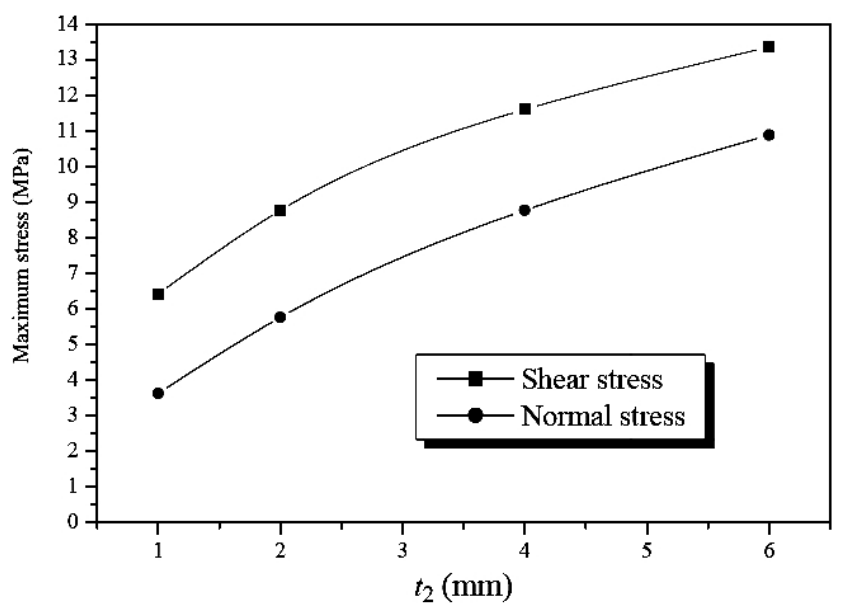

Fig. 6. Influence of thickness of CFRP strip on edge stresses $\left(\phi_{22}=0.12048\right.$ and $\left.\phi_{11}=3 \phi_{22}\right)$.

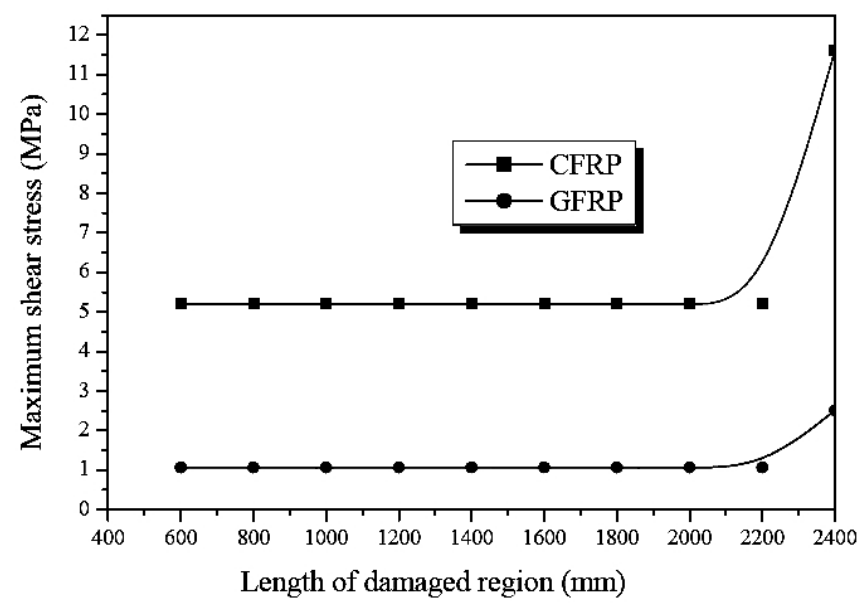

Fig. 7. Effect of the length of damaged region on the maximum interfacial shear stress $\left(\phi_{22}=0.12048\right.$ and $\phi_{11}=3 \phi_{22}$ ). 


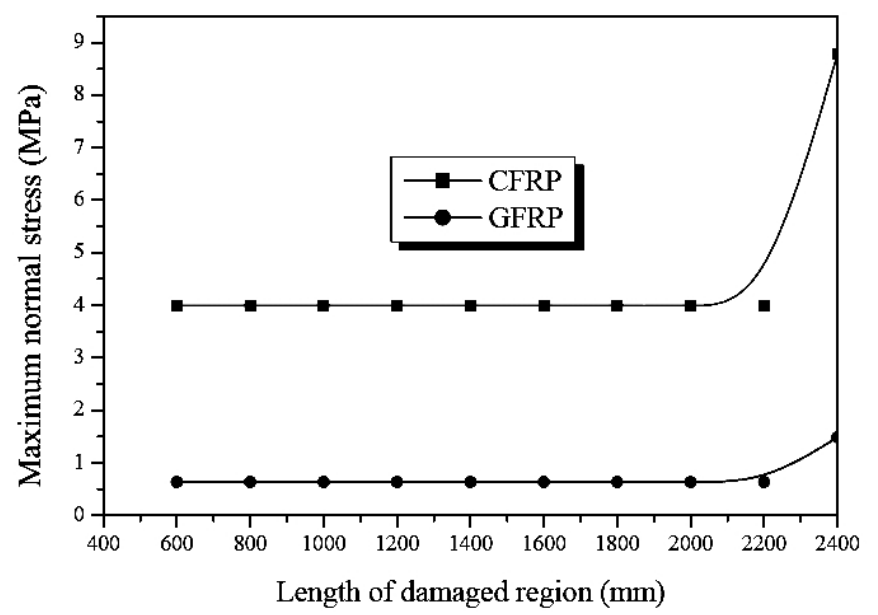

Fig. 8. Effect of the length of damaged region on the maximum interfacial normal stress $\left(\phi_{22}=0.12048\right.$ and $\left.\phi_{11}=3 \phi_{22}\right)$.

3.3. Effect of Length of Damaged Region. The influence of the length of the damaged region on the interfacial stresses is shown in Figs. 7 and 8. The range of the examined lengths is within 600-2400 mm for the two types of FRP strips. It is seen that while the length of the damaged region is less than the length of the strengthening plate $\left(D A<L_{p}\right)$, the edge peeling and shear stresses are constant. When the two lengths are equal $\left(D A=L_{p}\right)$, these stresses attain higher values. Consequently, it is recommended to use a strengthening plate having length, superior to the damaged zone.

Conclusions. This paper is concerned with the prediction of interfacial shear and normal stresses in damaged RC beams retrofitted with externally advanced composite materials. Such interfacial stresses provide the basis for understanding debonding failures in such beams and for development of suitable design rules. Numerical comparison between the existing solutions and the present new solution has been carried out. The anisotropic damage model is adopted to describe the damage of the RC beams. The results show that the damage has a significant effect on the interfacial stresses in FRP-damaged RC beam, especially, when the length of damaged region is equal or superior to the plate length. Consequently, it is recommended to use a strengthening plate having length, superior to the damaged zone. The results reveal also that thickness of the FRP strip significantly increases the edge peeling and shear stresses.

\section{Резюме}

Запропоновано аналітичние́ метод оцінки міжповерхневих напружень у шарі пошкоджених залізобетонних балок, що закріплені зовнішніми композитними пластинами з армованого волокнами вуглепластика. Запропоновано модель, яка, на відміну від існуючих рішень, враховує наявність міжповерхневих дотичних деформацій шляхом постулювання лінійного розподілу дотичних напружень по глибині залізобетонної балки. Розроблено анізотропну модель руйнування, що описує процес пошкодження залізобетонної балки. 
Установлено, що пошкодження суттєво впливає на величину міжповерхневих напружень у пошкоджених залізобетонних балках, армованих композитними пластинами.

1. T. C. Triantafillou, "Composites: a new possibility for the shear strengthening of concrete, masonry and wood," Compos. Sci. Technol., 58, No. 8, 12851295 (1998).

2. R. J. Quantrill and L. C. Hollaway, "The flexural rehabilitation of reinforced concrete beams by the use of prestressed advanced composite plates," Compos. Sci. Technol., 58, No. 8, 1259-1275 (1998).

3. U. Meier, M. Deuring, H. Meier, and G. Schwegler, "Strengthening of structures with advanced composites," in: J. L. Clarke (Ed.), Alternative Materials for the Reinforcement and Prestressing of Concrete, Glasgow (1993), pp. 153-171.

4. U. Meier, "Post strengthening by continuous fiber laminates in Europe," in: 3rd Int. Symp. on Nonmetallic (FRP) Reinforcement for Concrete Structures, Japan Concrete Institute, Sapporo (1997), pp. 42-56.

5. U. Meier, "Strengthening of structures using carbon fiber/epoxy composites," Constr. Build. Mater., 9, No. 6, 341-351 (1995).

6. S. E. Mouring, O. Barton, and D. K. Simmons, "Reinforced concrete beams externally retrofitted with advanced composites," Adv. Compos. Mater., 10, 139-146 (2001).

7. H. N. Garden and L. C. Hollaway, "An experimental study of the failure modes of reinforced concrete beams strengthened with prestressed carbon composite plates," Composites Part B, 29B, 411-424 (1998).

8. G. Spadea, F. Bencardino, and R. N. Swamy, "Structural behaviour of composite RC beams with externally bonded CFRP," J. Compos. Constr., 2, No. 3, 132-137 (1998).

9. O. Vilnay, "The analysis of reinforced concrete beams strengthened by epoxy bonded steel plates," Int. J. Cem. Compos. Lightweight Concr., 10, No. 2, 73-78 (1988).

10. S. T. Smith and J. G. Teng, "Interfacial stresses in plated RC beams," Eng. Struct., 23, No. 7, 857-871 (2001).

11. T. M. Roberts, "Approximate analysis of shear and normal stress concentrations in adhesive layer of plated RC beams," The Struct. Engr., 67, No. 12, 229233 (1989).

12. T. M. Roberts and H. Haji-Kazemi, "A theoretical study of the behaviour of reinforced concrete beams strengthened by externally bonded steel plates," ICE Proc., 87, No. 1, 39-55 (1989).

13. B. Taljsten, "Strengthening of beams by plate bonding," J. Mater. Civ. Eng., 9, No. 4, 206-212 (1997).

14. A. M. Malek, H. Saadatmanesh, and M. R. Ehsani, "Prediction of failure load of R/C beams strengthened with FRP plate due to stress concentration at the plate end," ACI Struct. J., 95, No. 2, 142-152 (1998). 
15. O. Rabinovich and Y. Frostig, "Closed-from high order analysis of RC beams strengthened with FRP strips," J. Compos. Constr., 4, No. 2, 65-74 (2000).

16. H. S. Shen, J. G. Teng, and J. Yang, "Interfacial stresses in beams and slabs bonded with a thin plate," J. Eng. Mech., 127, No. 4, 399-406 (2001).

17. G. Z. Voyiadjis and P. I. Kattan, "A plasticity-damage theory for large deformation of solids. Pt. I. Theoretical formulation," Int. J. Eng. Sci., 30, No. 9, 1089-1108 (1992).

18. T. Q. Yu, X. S. Miao, J. M. Xiong, et al., "An orthotropic damage model for concrete at different temperatures," Eng. Fract. Mech., 32, No. 5, 775-786 (1989).

19. H. S. Shen, Y. Chen, and W. L. Su, "Bending and vibration characteristics of damaged RC slabs strengthend with externally bonded CFRP sheets," Int. J. Compos. Struct., 63, 231-242 (2004). 